\title{
PENGENDALIAN PRODUKTIVITAS KERJA STAF PENGAJAR BERDASARKAN STRES PADA JURUSAN ADMINISTRASI BISNIS POLITEKNIK NEGERI PONTIANAK BERDASARKAN TEORI HIGGINS
}

\author{
Oleh: \\ Dedi Herdiansyah, Abdulah, dan Evi Sofiana \\ POLITEKNIK Negeri Pontianak
}

\section{ABSTRAK}

Keberhasilan suatu perusahaan/organisasi/lembaga sebagian besar tergantung pada sejauh mana tingkat keterampilan para karyawan dalam melaksanakan tugas mereka. Megelola sumber daya manusia secara efektif menjadi tanggungjawab setiap orang dalam satu perusahaan/organisasi/lembaga. Pemahaman yang komperehensif mengenai apa yang dilakukan oleh perusahaan yang efektif dalam lingkungan kompetitif untuk mengelola sumber daya manusia, perlu diketahui sebaik mungkin. Tema kunci dalam pengelolaan sumber daya manusia dewasa ini, antara lain : hubungan kemitraan (partnership), etika, globalisasi, pengelolaan perusahaan, kemajemukan (diversity), kerjasama tim (teamwork), serta kaitan sumber daya manusia dengan bisnis (Schuler dan Jackson, 1997:xiii).

Sumber daya manusia merupakan salah satu asset perusahaan yang paling utama oleh karena itu perlu dibina secara baik. Stres pada karyawan sebagai salah satu akibat dari bekerja perlu dikondisikan pada posisi yang tepat agar produktioitas mereka juga pada posisi yang diharapkan. Jurusan Administrasi Bisnis PoliteknikNegeri Pontianak merupakan salah satu Jurusan yang terus berkembang dan menyesuaikan diri dengan perkembangan pendidikan dan industri. Dalam tiga tahun terakhir selain menggunakan dana rutin lembaga, Jurusan Administrasi Bisnis sedang menjalankan Program Hibah Kompetisi (PHK A-2 2004-2006) yang merupakan program dari Dikti melalui Kegiatan Peningkatan Manajemen Pendidikan Tinggi (KPMPT), dalam rangka Dikti untuk mendorong meningkatkan kualitas pengelolaan manajemen semua Perguruan Tinggi yang ada di Indonesia untuk dapat menyediakan dan menghasilkan program pendidikan yang berkualitas sampai pada menghasilkan lulusan yang berkualitas dan mampu untuk bersaing di pasar kerja.

Dengan adanya program tersebut, dengan Stafjumlah Pengajar yang tersedia sebanyak 20 orang (5 orang sedang dikirim untuk melanjutkan program pendidikan $S$ 2 Nasional), sedangkan kelas yang dikelola sebanyak 11 kelas dari 3 angkatan, tentunya hal ini akan semakin menambah beban kerja bagi staf yang akan ditunjuk sebagai pengelola program. Hal ini terbukti dengan sebagian besar Staf Pengajar terplot sebagai pengelola, dari mulai Penanggungjawab Program sampai pada Person In Charge (PIC), untuk menjamin kelancaran dan keberhasilan kegiatan.

Untuk mengantisipasi jangan sampai terjadi beban kerja yang tidak seimbang, yang tentunya akan mengarah pada kinerja yang kurang baik. Maka peneliti memandang perlu dilakukan suatu penelitian dalam melihat posisi stress tiap Staf Pengajar Jurusan Administrasi Bisnis dalam rangka menjamin kinerja yang lebih baik, sehingga bisa dipilih Staf yang tepat untuk tanggungjawab kerja yang akan diberikan kepada Staf 
pengajar yang bersangkutan.

Penelitian ini bertujuan untuk mengetahui posisi stres Staf Pengajar di Jurusan Administrasi Bisnis Politeknik Negeri Pontianak. Dengan diketahuinya posisi stres ini, atasan atau manajer maupun superoisor dapat melakukan usaha-usaha agar posisi stres yang sudah tepat dapat dipertahankan sedangkan yang belum tepat perlu dicarikan upaya-upaya agar dapat memposisikan stres tersebut. Hasil penelitian kali ini menyimpulkan bahwa, dengan data penelitian yang diperoleh, tidak ada hubungan yang berarti yaitu antara stress dan prestasi kerja.

Menurut seorang ekonom dari Massachusetts Institute of Technology, Lester C. Thurow (dalam Schuler dan Jackson, 1997:5), satu alasan mengapa analis bisnis sangat menghargai manajemen SDM ialah karena perusahaan akan membutuhkan kemampuan karyawan dalam menghadapi kompetisi abad ke21. Beberapa penelitian terakhir menunjukkan bahwa perusahaan yang mengelola SDM-nya secara memiliki tingkat profitabilitas yang tinggi, penjualan tahunan perkaryawan yang tinggi (produktivitas), nilai pasar yang tinggi, dan pertumbuhan laba per saham yang tinggi, dengan kata lain, perusahaan-perusahaan ini dapat memenuhi kebutuhan organisasi, pemegang saham dan investor.

Keberhasilan suatu perusahaan/organisasi/lembaga sebagian besar tergantung pada sejauh mana tingkat keterampilan para karyawan dalam melaksanakan tugas mereka. Megelola sumber daya manusia secara efektif menjadi tanggungjawab setiap orang dalam satu perusahaan/organisasi/lembaga. Pemahaman yang komperehensif mengenai apa yang dilakukan oleh perusahaan yang efektif dalam lingkungan kompetitif untuk mengelola sumber daya manusia, perlu diketahui sebaik mungkin. Tema kunci dalam pengelolaan sumber daya manusia dewasa ini, antara lain : hubungan kemitraan (partnership), etika, globalisasi, pengelolaan perusahaan, kemajemukan (diversity), kerjasama tim (teamwork), serta kaitan sumber daya manusia dengan bisnis|(Schuler dan Jackson, 1997:xiii).

Berdasarkan tema kunci yang telah disebutkan sebelumnya, maka Politeknik Negeri Pontianak, yang juga sebagai suatu lembaga (pendidikan tinggi), menjalin hubungan kemitraan dengan stakeholder, beretika dengan lingkungan internal/eksternal, berwawasan global (sesuai dengan visi dan misi POLNEP), memiliki kemajemukan (baik SDM, teknologi, dan jasa lulusan), serta mengedepankan kerjasama, harus juga mampu mengelola sumber daya manusianya dalam menghadapi lingkungan penuh persaingan sekarang ini.

Sumber daya manusia merupakan salah satu asset perusahaan yang paling utama oleh karena itu perlu dibina secara baik. Stres pada karyawan sebagai salah satu akibat dari bekerja perlu dikondisikan pada posisi yang tepat agar produktivitas mereka juga pada posisi yang diharapkan.

Menurut Higgins, terdapat hubungan langsung antara stres dan prestasi kerja karyawan seperti model yang disajikan dibawah ini. 
Gambar 1.

Model Higgins

Tentang Hubungan Produktivitas Kerja dan Stres

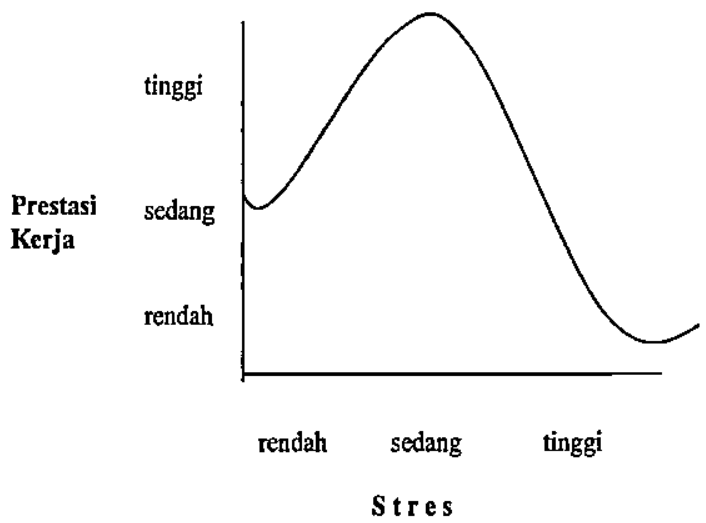

Dari model di atas dapat dilihat bahwa stres mempunyai potensi untuk mendorong atau mengganggu pelaksanaan kerja, tergantung dari berapa besar tingkat stres. berikut :

Dari diagram di atas, maka posisi tingkat stres dapat dilihat pada table

Tabel 1.

Posisi antara Prestasi Kerja dengan Tingkat Stres

Tingkat stress

$(X)$

Rendah

Sedang

Tinggi
Prestasi Kerja

(Y)

Sedang

Tinggi

Rendah

Dengan mengetahui variable $Y$ (dependen) yaitu beberapa gejala stres, serta variable $X$ (independen) yaitu variable prestasi kerja, dapat dilihat posisi stres dan prestasi kerja dengan menggunakan alat ukur statistika, antara lain diagram dan korelasi (rank spearman).

Selanjutnya menurut Higgins pula, data yang dibutuhkan untuk menganalisis permasalahan di atas adalah (Umar, 2001:265-266);

1) Variable stres, yaitu berupa gejala stres yang terdiri dari komponen-komponen:

* Penggunaan obat penenang

* Tekanan darah

* Rasa sakit pada kepala

*Nyeri punggung

* Ucapan-ucapan yang tidak menyenangkan

* Susah tidur

* Nyeri dada 
* Jantung berdebar

* Sesak nafas karena emosi

* Penggunaan obat tidur

* Terbangun pada malam hari

* Rasa letih

* Kurang nafsu makan

* Kurang tidur

* Perasaan cemas

* Mudah marah

* Keinginan untuk merubah suasana

* Merasa kehilangan waktu kerja

* Perasaan akan sesuatu yang makin kritis

* Perasaan diperbudak pekerjaan

* Sering mengalami kecelakaan

* Kehilangan kepercayaan diri

* Bosan terhadap pekerjaan

* Kehilangan kepercayaan pada perusahaan

2) Variabel Kinerja

* Mutu pekerjaan

* Kejujuran karyawan

* Inisiatif

* Kehadiran

* Sikap

* Kerjasama

* Keandalan

* Pengetahuan tentang pekerjaan

* Tanggungjawab

* Pemanfaatan waktu

Mengacu kepada model di atas, variable prestasi kerja dan variable stres minimal berskala ordinal agar dapat diplot pada diagram. Higgins pun mengatakan bahwa jika minimum 3 deskriptor Gejala Stres telah dimiliki maka Staf Pengajar tersebut telah terkena stres, hanya disesuaikan dengan tingkat stresnya.

Jurusan Administrasi Bisnis Politeknik Negeri Pontianak merupakan salah satu Jurusan yang terus berkembang dan menyesuaikan diri dengan perkembangan pendidikan dan industri. Dalam tiga tahun terakhir selain menggunakan dana rutin lembaga, Jurusan Administrasi Bisnis sedang menjalankan Program Hibah Kompetisi (PHKA-2 2004-2006) yang merupakan program dari Dikti melalui Kegiatan Peningkatan Manajemen Pendidikan Tinggi (KPMPT), dalam rangka Dikti untuk mendorong meningkatkan kualitas pengelolaan manajemen semua Perguruan Tinggi yang ada di Indonesia untuk dapat menyediakan dan menghasilkan program pendidikan yang berkualitas sampai pada menghasilkan lulusan yang berkualitas dan mampu untuk bersaing di pasar kerja.

Dengan adanya program tersebut, dengan Staf Pengajar yang tersedia sebanyak 20 orang ( 5 orang sedang dikirim untuk melanjutkan program pendidikan S-2 Nasional), sedangkan kelas yang dikelola sebanyak 11 kelas dari 3 angkatan, tentunya hal ini akan semakin menambah beban kerja bagi staf yang akanditunjuk 
sebagai pengelola program. Hal ini terbukti dengan sebagian besar Staf Pengajar terplot sebagai pengelola, dari mulai Penanggungjawab Program sampai pada Person In Charge (PIC), untuk menjamin kelancaran dan keberhasilan kegiatan.

Untuk mengantisipasi jangan sampai terjadi beban kerja yang tidak seimbang, yang tentunya akan mengarah pada kinerja yang kurang baik. Maka peneliti memandang perlu dilakukan suatu penelitian dalam melihat posisi stress tiap Staf Pengajar Jurusan Administrasi Bisnis dalam rangka menjamin kinerja yang lebih baik, sehingga bisa dipilih Staf yang tepat untuk tanggungjawab kerja yang akan diberikan kepada Staf pengajar yang bersangkutan.

\section{A.1. Perumusan Masalah}

Sehingga dengan latar belakang tersebut, maka penulis menganggap penting untuk meneliti sumber daya manusia dari berbagai sisi, dalam hal ini peneliti ingin meneliti sumber daya manusia dari sisi "Pengendalian Produktivitas Staf Pengajar Berdasarkan Stres Pada Jurusan Admsinistrasi Bisnis Politeknik Negeri Pontianak" dengan mengadopsi Model Higgins (Umar, 2001:155).

\section{A.2. Tujuan Penelitian}

Penelitian ini bertujuan untuk mengetahui posisi stres Staf Pengajar di Jurusan Administrasi Bisnis Politeknik Negeri Pontianak. Dengan diketahuinya posisi stres ini, atasan atau manajer maupun supervisor dapat melakukan usahausaha agar posisi stres yang sudah tepat dapat dipertahankan sedangkan yang belum tepat perlu dicarikan upaya-upaya agar dapat memposisikan stres tersebut.

\section{A.3. Manfaat Penelitian}

Penelitian ini diharapkan dapat memberikan masukan bagi Ketua Jurusan Administrasi Bisnis tentang posisi Prestasi Kerja dan Stress tiap-tiap Staf Pengajar Jurusan Administrasi Bisnis. Dengan mengetahui posisi yang dimaksud, dapat dijadikan sebagai bahan pertimbangan dalam membuat kebijakan menyangkut pemberian beban tugas terhadap Staf Pengajar tertentu. Staf mana yang perlu dikurangi beban kerjanya dan Staf mana yang masih bisa dipertimbangkan untuk ditambah beban kerja sesuai wewenang masing-masing.

\section{B. LANDASAN TEORI}

\section{B.1. Teori Stress}

Mengutip pengertian Stress dari Handoko (1993), stress merupakan suatu kondisi ketegangan yang mempengaruhi emosi, proses berpikir dan kondisi seseorang. Kondisi yang cenderung menyebabkan stress disebut stressor. Menurut Cary Cooper dan Alison straw (1992) dari British Institute of Management, gejala stres dapat dilihat dari 3 sisi, yaitu :

1. Gejala Fisik:

* Nafas memburu

* Mulut dan kerongkongan kering

*Tanagan lembab

* Merasa panas

* Otot-otot tegang

* Pencernaan tergganggu 
* Mencret-mencret

* Sembelit

* Letih yang tak beralasan

* Sakit Kepala

* Salah urat

*Gelisah

2. Tingkah laku (secara umum)

Perasaan:

* Bingung, cemas, sedih

* Jengkel

*Salah paham

* Tak Berdaya

* Tak mampu berbuat apa-apa

* Gelisah

* Merasa gagal

* Kehilangan semangat

Kesulitan dalam:

*Berkonsentrasi

* Berpikir jernih

* Membuat keputusan

Hilangnya:

* Kretaivitas

* Gairah dalam penampilan

* Minat terhadap orang lain

3. Gejala-gejala di tempat kerja

* Kepuasan kerja rendah

* Kinerja yang menurun

* Semangat dan enerji menurun

* Komunikasi tak lancar

* Pengambilan keputusan yang jelek

* Kreativitas dan inovasi berkurang

* Bergulat pada tugas -tugas yang tidak produktif

\section{B.2. Teori Produktivitas}

Produktivitas menurut Dewan Produktivitas Nasional (dalam Umar, 2001:9) mempunyai pengertian sebagai sikap mental yang selalu berpandangan bahwa mutu kehidupan hari ini harus lebih baik dari kemarin dan harj esok lebih baik dari hari ini. Sedangkan secara umum seperti banyak yang terdapat dalam bukubuku teks tentang produktivitas, produktivitas mengandung arti sebagai perbandingan antara hasil yang dicapai (output) dengan keseluruhan sumber daya yang digunakan (input). Dengan kata lain bahwa produktivitas memiliki dua dimensi. Dimensi pertama adalah efektivitas yang mengarah kepada pencapaian unjuk kerja yang maksimal yaitu pencapaian target yang berkaitan dengan kualitas, kuantitas, dan waktu. Yang kedua yaitu efisiensi yang berkaitan dengan upaya membandingkan input dengan realisasi penggunaannya atau bagaimana pekerjaan tersebut dilaksanakan.

Efisiensi merupakan satu ukuran dalam membandingkan input yang 
direncanakan dengan input yang sebenarnya. Apabila input yang sebenarnya digunakan semakin besar penghematannya, maka tingkat efisiensi semakin tinggi. Tetapi semakin kecil input yang dapat dihemat akan semakin rendah tingkat efisiensinya. Efektivitas merupakan ukuran yang memberikan gambaran seberapa jauh target dapat dicapai. Apabila efisiensi dikaitkan dengan efektivitas, walaupun terjadi peningkatan efektivitas, efisiensinya belum tentu meningkat.

Selanjutnya, keterkaitan aritara efisiensi, efektivitas, kualitas, dan produktivitas dapat dirangkai dalam skema seperti berikut :

Gambar 2

Keterkaitan antara Efisiensi, Efektivitas, Kualitas

Dan Produktivitas
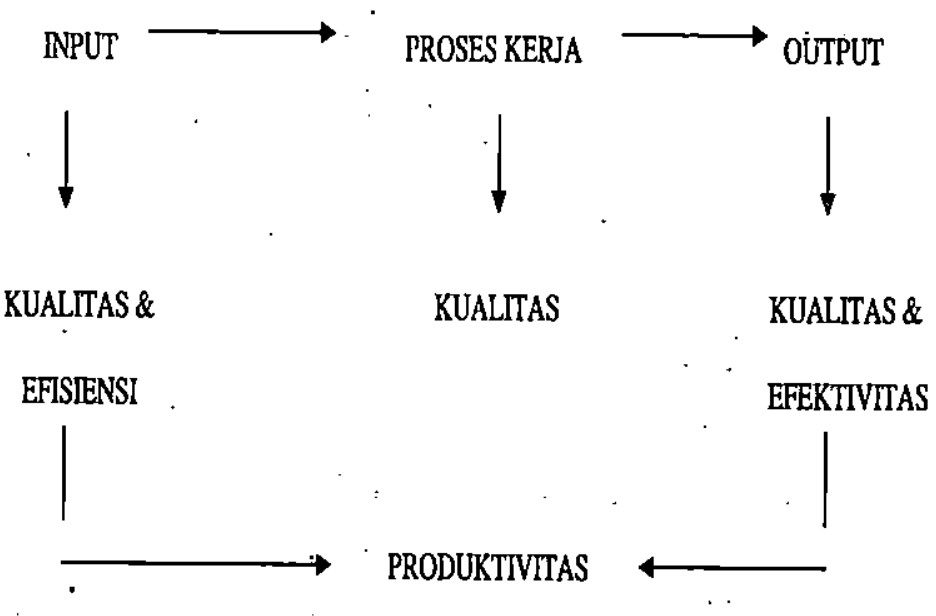

Menurut Larsen yang dikutip Umar (2001:11), unjuk kerja (job performance) yang baik dapat dipengaruhi oleh kecakapan dan motivasi. Kecakapan tanpa motivasi atau motivasi tanpa kecakapan sulit untuk mendapatkan output yang tinggi. Untuk mencapai produktivitas kerja yang maksimum organisasi harus menjamin dipilihnya orang yang tepat dengan pekerjaan yang tepat serta kondisi yang memungkinkan mereka bekerja optimal.

Sedarmayanti (1995), seperti yang dikutip Umar (2001:11-12), mengatakan ciri-ciri individu yang produktif dari Erich dan Gilmore, yaitu :

- Tindakannya konstruktif

* Percaya diri

* Mempunyai rasa tanggung jawab

* Memiliki rasa cinta terhadap pekerjaannya

* Mempunyai pandangan ke depan

* Mampu menyelesaikan persoalan

* Dapat menyesuaikan diri dengan lingkungan yang berubah

* Mempunyai kontribusi positif terhadap lingkungan

* Mempunyai kekuatan untuk mewujudkan potensinya. 
Sedangkan ciri pegawai yang produktif menurut Dale Timpe (1989), seperti yang dikutip Umar (2001:12) adalah:

* Cerdas dan dapat belajar dengan relatif cepat.

* Kompeten secara profesional.

* Kreatif dan inovatif.

* Memahami pekerjaan.

* Belajar dengan cerdik, menggunakan logika, efisien, tidak mudah macet dalam pekerjaan.

* Selalu mencari perbaikan-perbaikan, tetapi tahu kapan harus berhenti

* Dianggap bernilai oleh atasannya.

* Memiliki catatan prestasi yang baik.

* Selalu meningkatkan diri.

Ada korelasi langsung antara stres dengan prestasi kerja. Menurut Higgins, bila karyawan tidak memiliki stres maka tantangan-tantangan kerja tidak ada dan akibatnya prestasi kerja juga rendah (Umar, 2001:35). Makin tinggi stres karena tantangan kerja yang juga bertambah maka akan mengakibatkan prestasi kerja juga bertambah, tetapi jika stres sudah maksimal, tantangan-tantangan kerja jangan ditambah karena tidak lagi akan dapat meningkatkan prestasi kerja, malah akan menurunkan prestasi kerjanya.

\section{B.3. Teori Kinerja}

Penilaian Kinerja (performance appraisal-PA) adalah evaluasi seberapa baik karyawan mengerjakan pekerjaan mereka ketika dibandingkan dengan dengan satu set standar, dan kemudian mengkomunikasikannnya dengan para karyawan. Penilaian ini demikian juga disebut sebagai penilaian karyawan, evaluasi karyawan, tinjauan kinerja, evaluasi kinerja, dan penilaian hasil. (Mathis dan Jackson, 2002:80)

Menurut Mangkunegara (2001:67), kinerja adalah "Hasil kerja secara kualitas dan kuantitas yang dicapai oleh seorang pegawai dalam melaksanakan tugasnya sesuai dengan tanggung jawab yang diberikan kepadanya".

Manajemen maupun karyawan perlu umpan balik tentang kerja mereka. Hasil penilaian prestasi kerja (performance appraisal) karyawan dapat memperbaikj keputusan-keputusan personalia dan memberikan umpan balik kepada karyawan tentang pelaksanaan kerja mereka. Agar penilaian prestasi kerja dapat dilaksanakan dengan baik, maka hal itu perlu dipersiapkan! Sistem-sistem penilaian harus mempunyai hubungan dengan pekerjaan, praktis, memiliki standar-standar, dan menggunakan ukuran yang dapat diandalkan (Husein Umar, 2001:14-15).

Selanjutnya, penilai pun perlu dipersiapkan. Penilai sering tidak berhasil untuk tidak melibatkan emosinya dalam menilai karyawan. Hal ini dapat terjadi karena berbagai macam faktor, yaitu : hailo effect (enggan menilai hal-hal yang ekstrim walau seharusnya secara obyektif bernilai ekstrim), menilai terlalu lunak atau terlalu keras, prasangka pribadi, serta menilai berdasarkan data atau fakta dari waktu yang paling akhir saja.

Evaluasi kinerja berpotensi sebagai piranti paling kritis yang bisa digunakan untuk mempengaruhi karyawan. Ada dua aspek dalam evaluasi kinerja yaitu penilaian kinerja dan perencanaan kinerja. Penilaian kinerja menilai kinerja seseorang karyawan selama tahun lalu - ia menengok ke belakang, ke masa 
lalu. Perencanaan kinerja berkaitan dengan upaya meingkatkan kinerja karyawan dan merencanakan pekerjaan masa mendatang - memandang ke depan. Dengan demikian evaluasi kinerja yang baik tidak hanya merangkum masa lalu tetapi juga membantu menetapkan kinerja masa mendatang.

Evaluasi yang sistematis penting bagi organisasi-organisasi karena alasanalasan sebagai berikut: (Sheal, 2003:223-224)

1. Menuntut para manajer agar berkomunikasi dengan staf mereka dan mendiskusikan kinerja individual. Evaluasi kinerja bisa memaksa para manajer untuk menghadapi masalah-masalah kinerja yang buruk dan berusaha memecahkannya.

2. Memberikan pembenaran atas kenaikan-kenaikan tunjangan. Karena gaji staf seringkali termasuk membayar karyawan sesuai kinerja, maka sumbangan individu pada organisasi perlu ditimbang dengan adil dan jujur.

3. Mengidentifikasi kebutuhan-kebutuhan karyawan akan dukungan dan pelatihan. Ketika anda bertemu dengan staf untuk mengevaluasi kinerja mereka pada tahun lalu dan menetapkan sasaran masa depan mereka. Anda bisa membahas bidang-bidang di mana dukungan atau pelatihan tambahan mungkin akan membantu.

4. Memberikan informasi yang mutakhir mengenai keterampilan-keterampilan dan keahlian staf, sehingga bisa digunakan untuk perencanaan tenaga kerja. Melalui evaluasi kinerja, organisasi memiliki piranti yang lebih lengkap untuk menyesuaikan keterampilan-keterampilan, aspirasi-aspirasi karier, dan pengalaman dengan slot-slot pekerjaan yang sudah ada atau yang telah direncanakan.

\section{RANCANGAN PENELITIAN}

Bentuk penulisan yang dipergunakan dalam penelitian ini adalah penulisan deskriptif, yaitu yang menggambarkan suatu keadaan atau kejadian pada saat sekarang berdasarkan fakta-fakta sebagaimana adanya, sehingga dapat menggambarkan keadaan dari obyek yang diteliti dan yang menjadi obyek dalam penelitian. Penelitian yang akan dilakukan ini juga merupakan penelitian survey, yaitu suatu peneltian yang dilakukan dengan mengambil sample dari populasi dan menggunakan sebagai kuisioner sebagai alat pengumpulan data pokok (Singarimbun dan Effendy, 1995:3).

\section{C.1. Data Penelitian}

* Data yang dibutuhkan akan ditampung pada lembar kuisioner yang berisi kedua variable di atas untuk masing-masing data karyawan. Untuk variable stres dan variable kinerja sebagian dapat ditanyakan kepada karyawan (kecuali untuk data yang memerlukan pengukuran obyektif).

* Untuk pengukuran yang berkesinambungan (longitudinal research) sudah tentu data dari Staf Pengajar diambil secara periodik, yaiłu tiap bulan sehingga dapat dilihat perkembangan dari bulan ke bulan.

* Tiap deskriptor diberi skala dengan skor 1 sampai 5 . Untuk variable stres, skor yang diberikan :
$1=$ sangat rendah
$4=$ tinggi
$2=$ rendah
$5=$ sangat tinggi
$3=$ sedang 
Untuk prestasi kerja, skor yang diberikan:

1 = sangat jelek

$4=$ baik

$2=$ jelek

5 = sangat baik

$3=$ sedang

Untuk memperoleh data dari responden, menurut Higgins, alangkah baiknya jika peneliti menggunakan alat ukur yang tepat dan teruji, misalnya untuk mengetahui tekanan darah tinggi (deskriptor nomor 2), responden tidak dapat dengan mengira-ngira apakah tekanan darahnya menjadi tinggi atau tidak, tetapi hendaknya tekanan darah tinggi telah diukur dengan alat ukur tekanan darah tinggi. Juga pada variable kinerja, deskriptor mutu pekerjaan sebaiknya tidak ditanyakan kepada karyawah, tetapi diambil dari hasil penilaian obyektif yang telah menggunakan aturan yang jelas. Selanjutnyà dari angka-angka hasil-hasil pengukuran obyektif ini, dapat ditransfer dalam skala ordinal atau interval, sesuai dengan modelnya.

\section{C.3. Populasi dan Sampel}

Populasi menurut Sugiyono (2003:90) adalah: 'Wilayah generalisasi yang terdiri dari obyek/subyek yang mempunyai kualitas dan karakteristik tertentu yang ditetapkan oleh peneliti untuk dipelajari dan kemudian ditarik kesimpulannya". Yang akan menjadi Populasi dalam penelitian ini adalah Seluruh Staf Pengajar di Jurusan Administrasi Bisnis Politeknik Negeri Pontianak yang berjumlah 20 orang. Sehubungan dengan dikirimnya 5 orang Staf untuk melanjutkan pendidikan Program S-2 dan 1 orang Staf merangkap Pembantu Direktur Ill Polnep, maka populasi tersisa sebanyak 14 orang.

Sedangkan Sampel adalah "Sebagian jumlah dari karakteristik yang dimiliki populasi", (Sugiyono, 2003:91). Maka yang akan menjadi sampel penelitian ini adalah 14 orang Staf Pengajar pada Jurusan Administrasi Bisnis Polnep.

\section{C.4. Alat Ukur}

* Diagram

Setiap Staf Pengajar mempunyai diagram sendiri-sendiri. Diagram ini memperlihatkan titik-titik pada periode-periode penelitian dimana titiktitik itu merupakan titik temu dari nilai stres dengan nilai prestasi kerja.

" Korelasi

Alat ukur untuk mengukur seberapa besar pengaruh stres pada prestasi kerja karyawan dapat menggunakan alat ukur statistika yang disebut korelasi. Korelasi yang dipakai adalah korelasi rank spearmen (Rs)

Dimana Rumus Rank Spearmen (Rs) adalah sebagai berikut:

$$
\begin{aligned}
\mathrm{R}_{\mathrm{s}}=1-\frac{6 \sum d_{i}^{2}}{n\left(n^{2}-1\right)} & \\
& \quad \operatorname{dimana}^{2} \\
& \sum d_{i}^{2}=\sum\left[R\left(X_{i}\right)-R\left(Y_{i}\right)\right]^{2}
\end{aligned}
$$




\section{C.5. Pengolahan Data dan Interpretasi}

* Jika mengacu pada Higgins, seseorang telah terkena stres kalau minimal tiga gejala stres memiliki skor tinggi, maka akan diseleksi data responden yang berkategori stres.

* Data yang terkumpul dikelompok-kelompokkan, lalu dicari skornya.

* Rata-rata skor untuk kedua variable di atas dapat dibuat dalam scatter-diagram dengan menggabungkan kedua nilai menjadi sebuah titik temu. Untuk data beberapa periode, gabungkan titik-titiknya menjadi sebuah kurva. Bandingkan dengan model teori dari Higgins di atas.

* Nilai kinerja seseorang bisa saja dipengaruhi oleh hal-hal lain selain yang telah ditentukan di atas. Untuk mengetahui berapa besar kontribusi stres terhadap kinerja Staf Pengajar, kita dapat menghitungnya dengan menggunakan model statistika, yaitu menggunakan korelasi rank spearman (Rs).

* Hipotesis penelitian :

Ho:tidak ada hubungan yang berarti antara stres dan produktivitas kerja

Ha:ada hubungan yang berarti antara stres dan produktivitas kerja

D. GAMBARAN UMUM JURUSAN ADMINISTRASI BISNIS POLITEKNIK NEGERI PONTIANAK

\section{D.1. Tujuan dan Prioritas Pengembangan Perguruan Tinggi}

Perkembangan dunia usaha, industri dan perkantoran saat ini di Propinsi Kalimantan Barat maju cukup pesat yang ditandai dengan semakin banyak dibuka lapangan usaha dan jasa perdagangan baru. Kondisi ini berdampak positif terhadap kebutuhan tenaga profesional yang trampil di bidang bisnis dan perkantoran. Keberadaan Jurusan Administrasi Bisnis dinilai sudah sangat tepat untuk menjawab kebutuhan tenaga kerja tersebut. Untuk itu pengembangan perguruan tinggi harus terus dilakukan dan terutama diarahkan untuk peningkatan daya saing lulusan.

Politeknik Negeri Pontianak (POLNEP) sebagai salah satu lembaga pendidikan tinggi yang menghasilkan lulusan siap pakai dari Program Pendidikan Diploma Ili terus melakukan upaya pengembangan dalam rangka meningkatkan kualitas pendidikan dan ikut serta mendorong perkembangan daerah Kalimantan Barat. Sampai tahun 2006 ini, Politeknik Negeri Pontianak telah memiliki beberapa Jurusan dan Program Studi, diantaranya Jurusan Administrasi Bisnis, Jurusan Akuntansi, Jurusan Teknik Sipil, Program Studi Arsitek, Jurusan Teknik Elektro, Jurusan Teknik Mesin, Jurusan Teknologi pengolahan Hasil Perkebunan dan yang terakhir adalah Jurusan IImu Kelautan dan Perikanan.

D.2. Visi dan Misi Politeknik Negeri Pontianak

Sebagai lembaga pendidikan Diploma IIl kepoliteknikan, dalam kegiatan operasionalnya Jurusan Administrasi Bisnis berdasarkan pada visi dan misi dan tujuan jurusan yang tentunya tidak menyimpang dan merupakan kesatuan yang integral dari visi dan misi Politeknik Negeri Pontianak. Adapun Visi Global Politeknik Negeri Pontianak 2020 adalah :

Pada tahun 2020, Polnep merupakan lembaga pendidikan tinggi profesional yang berkualitas baik ditingkat nasional maupun internasional, 
Dedi Herdiansyah, Abdulah, dan Evi Sofiana: Pengendalian Produktivitas Kerja Staf Pengajar...

memiliki keunggulan komperatif dan kompetitif di bidang penyelenggaraan pendidikan profesional dan penelitian terapan, menghasi|kan lulusan yang mempunyai pengetahuan, sikap dan keterampilan yang mudah beradaptasi dengan perkembangan jaman dengan menonjolkan kemampuan berkomunikasi, kemandirian dan berwawasan kedepan serta menjunjung tinggi nilai-nilai moral, budaya dan kemanusiaan untuk mendukung kesejahteraan hidup masyarakat.

Untuk mendukung pelaksanaan visi global tersebut dirumuskan misi POLNEP adalah :

1. Menyelenggarakan pendidikan vokasi dan penelitian terapan bagi peningkatan kesejahteraan masyarakat guna menunjang upaya. pembangunan nasional, sesuai dan sepadan dengan kebutuhan masyarakat.

2. Membina dan mengembangkan profesionalisme yang sehat dan dinamis.

3. Mengembangkan dan mendayagunakan ilmu pengetahuan dan teknologi untuk meningkatkan kesejahteraan masyarakat dengan memberdayakan sumberdaya Politeknik Negeri Pontianak secara maksimum.

\section{D.3. Visi dan Misi Jurusan Adminsitrasi.Bisnis}

Sejalan dengan visi dan misi Polnep di atas, maka visi dan misi Jurusan Administrasi Bisnis adalah:

Pada tahun 2020 Jurusan Administrasi Bisnis Politeknik Negeri Pontianak menjadi penyelenggara pendidikan vokasional terdepan bidang Adminstrasi Bisnis dalam menyiapkan tenaga kerja profesional yang memiliki kepribadian, keunggulan komparatif dan kompetitif baik ditingkat nasional maupun internasional.

Misi jurusan adalah :

a. Menghasilkan lulusan profesional yang dapat berfikir ilmiah dalam memecahkan berbagai persoalan yang berkaitan dengan bidang administrasi bisnis, dengan efektif dan efisien.

b. Membentuk dan menghasilkan lulusan yang berbudi luhur dan mempunyai integritas tinngi, profesional dalam mengaplikasikan ilmu pengetahuan dan teknologi terapan bidang administràsi Bisnis di sektor industri.

c. Menyelenggarakan pendidikan dan pelatihan, penelitian dan pengabdian pada masyarakat dalam rangka pengembangan sumber daya manusia khususnya bidang administrasi Bisnis bagi industri dan bisnis.

Pendidikan Diploma III Jurusan Administrasi Bisnis mempunyai tujuan untuk menghasilkan tenaga ahli madya profesiopal dalam bidang administrasi Bisnis dan perkantoran yang berorientasi pada kebutuhan dunia usaha dan industri, dengan sepesifikasi:

1. Memiliki kepribadian yang bernilai takwa, dan integritas nasional Indonesia

2. Mampu menerapkan pengetahuan dasar mengenai dunia bisnis, prinsipprinsip ekonomi, masalah keuangan, manajemen, perbankan dan hukum perdata/dagang secara umum 
3. Menguasai kemampuan dalam bidang administasi Bisnis yang bersifat rutin, maupun tidak rutin secara mandiri dan mampu melakukan pengawasan dalam lingkup kerjanya.

4. Mampu mengisi jabatan-jabatan dan dapat melaksanakan tugasnya dibidang Administrasi Bisnis.

5. Menguasai secara menyeluruh semua hal yang berkaitan ciengan administrasi dan perkantoran

6. Dapatberkomunikasi dalam bahasa Inggris, dan bahasa Mandarin baik lisan maupun tulisan dalam menjalankan profesinya.

7. Dapat beradaptasi dengan perkembangan ilmu pengetahuan dan teknologi administrasi Bisnis serta situasi dan kondisi dunia kerja nyata.

8. Mampu melaksanakan tugas administrasi informasi yang menunjang pekerjaan administrasi

9. Mampu merencanakan dan memimpin, mengendalikan pelaksanaan kegiatan ketatausahaan baik bagi atasan maupun unit kerja

10. Mampu melaksanakan kegiatan kesekretariatan.

11. Mampu melaksanakan pekerjaan berdasarkan etika profesi Bisnis

12. Mampu menjaga hubungan baik dengan masyarakat internal maupun eksternal.

\section{D.4. Prioritas Program kegiatan Jurusan Administrasi Bisnis}

Untuk mewujudkan visi dan misi Politeknik Negeri Pontianak dan Jurusan Administrasi Bisnis tersebut di atas Jurusan Administrasi Bisnis telah merumuskan program kegiatan 5 (lima) tahun ke depan dengan menekankan pada penciptaan tenaga professional di bidang Administrasi Bisnis yang memiliki daya saing yang tinggi baik nasional maupun internasional melalui :

1. Program Peningkatan Manajemen Jurusan, melalui;

a. Meningkatkan pelayanan administrasi

b. Meningkatkan profesionalisme staf Administrasi dan Teknisi

c. Meningkatkan manajemen data (arsip)

d. Meningkatkan sistem evaluasi staf dan mahasiswa dalam proses pembelajaran

2. Program peningkatan daya saing lulusan, melalui;

a. Mempertahankan dan meningkatkan Indeks Prestasi mahasiswa.

b. Meningkatkan daya serap lulusan pada dunia kerja.

c. Memperpendek waktu tunggu lulusan untuk memperoleh pekerjaan.

d. Meningkatkan penghargaan terhadap lulusan (penghasilan yang diperoleh).

e. Sertifikasi dari dunia industri dan asosiasi profesi.

3. Program Peningkatan Kerjasama dengan dunia luar (dunia industri dan asosiasi profesi)

Melalui program kegiatan 5 tahun ke depan tersebut diharapkan Jurusan Administrasi Bisnis dapat menghasilkan lulusan yang memiliki daya saing yang tinggi, memiliki sertifikasi, dari mendapatkan penghargaan yang sesuai dengan kompetensi yang dimiliki. 
Dedi Herdiansyah, Abdulah, dan Evi Sofiana: Pengendalian Produktivitas Kerja Staf Pengajar...

\section{E. HASIL DAN PEMBAHASAN}

\section{E.1. Data Responden Staf Pengajar Jurusan Administrasi.Bisnis Politeknik Negeri Pontianak}

Staf Pengajar Jurusan Administrasi Bisnis Politeknik Negeri Pontianak berjumlah 20 orang, 5 orang berangkat penididikan Program S-2, jadi jumlah Staf yang ada sebanyak 15 orang Staf termasuk Ketua Jurusan. Jadi yang menjadi sample untuk penelitian ini adalah sebanyak 14 orang Staf.

Tabel 1.

Data Nama dan Usia Responden Penelitian

\begin{tabular}{|c|c|c|c|}
\hline No & Nama Responden & Tempat Tangal Lahir & \begin{tabular}{|c|} 
Usia sampai \\
2006
\end{tabular} \\
\hline 1 & Abdullah, SE, MM & Pontianak, 06 September 1963 & 43 tahun \\
\hline 2 & Ardhisty, SE & Jakarta, 10 Mei 1982 & 24 tahun \\
\hline 3 & Dedi Herdiansyah, SE, MSi & Sambas, 09 Oktober 1975 & 31 tahun \\
\hline 4 & Desvira Zain, SE, MM & Bah jambi, 15 Desember 1973 & 33 tahun \\
\hline 5 & Drs. Didi Zulyanto & Sintang, 14 April 1964 & 42 tahun \\
\hline 6 & Evi Sofiana, SE & Pontianak, 06 September 1977 & 29 tahun \\
\hline 7 & Ismail Umar, SE, MM & Pontianak, 03 Mei 1968 & 38 tahun \\
\hline 8 & Lilyana, SE & Sui Ambawang, 11 maret 1978 & 28 tahun \\
\hline 9 & Dra. Lilis Listyawati & Singkawang, 21 September 1967 & 39 tahun \\
\hline 10 & Mahendra Jaya, SE; MM & Bukit Tinggi, 05 Mei 1962 & 44 tahun \\
\hline 11 & Sri Syabanita Elida, SE, MM & Pontianak, 04 Agustus 1976 & 30 tahun \\
\hline 12 & Syarifan Novieyana, SE & Pontianak, 10 Juni 1977 & 2y) tahun \\
\hline 13 & Marcela Diaz, SE & Jakarta, 16 Maret 1981 & 20 tahun \\
\hline 14 & Utin Nina Hermina, SE, MSi & Pontianak, 30 September 1971 & 35 tahun \\
\hline
\end{tabular}

\section{Sumber : Data Primer 2006}

Dari tabel tersebut dapat diketahui bahwa rata-rata usia Staf Pengajar Jurusan Administrasi Bisnis Politeknik Negeri Pontianak masih berusia muda yaitu antara 24 tahun sampai 44 tahun, dengan rata-rata usialyaitu 33 tahun. 
E.2. Pengolahan Data dan Interpietasi -

* Jika mengacu pada Higgins, seseorang telah terkena stres kalau minimal tiga gejala stres memiliki skor tinggi, maka akan diseleksi data responden yang berkategori stres.

* Data yang terkumpul dikelompok-kelompokkan, lalu dicari skornya.

* Rata-rata skor untuk kedua variable di atas dapat dibuat dalam scatter-diagram dengan menggabungkan kedua nilai menjadi sebuah titik temu. Untuk data beberapa periode, gabungkan titik-titiknya menjadi sebuah kurva. Bandingkan dengan model teori dari Higgins di atas.

" Nilai kinerja seseorang bisa saja dipengaruhi oleh hal-hal lain selain yang telah ditentukan di atas. Untuk mengetahui berapa besar kontribusi stres terhadap kinerja Staf Pengajar, kita dapat menghitungnya dengan menggunakan model statistika, yaitu menggunakan korelasi rank spearman (Rs).

* Hipotesis penelitian:

Ho : tidak ada hubungan yang berarti antara stres dan produktivitas kerja $\mathrm{Ha}$ : ada hubungan yang berarti antara stres dan produktivitas kerja

\section{E.3. Data Penelitian Hasil Kuisioner}

Untuk memperoleh data dari responden, menurut Higgins, alangkah baiknya jika peneliti menggunakan alat ukur yang tepat dan teruji, misalnya untuk mengetahui tekanan darah tinggi (deskriptor nomor 2), responden tidak dapat dengan mengira-ngira apakah tekanan darahnya menjadi tinggi atau tidak, tetapi hendaknya tekanan darah tinggi telah diukur dengan alat ukur tekanan darah tinggi. Juga pada variable kinerja, deskriptor mutu pekerjaan sebaiknya tidak ditanyakan kepada karyawan, tetapi diambil dari hasil penilaian obyektif yang telah menggunakan aturan yang jelas. Selanjutnya dari angka-angka hasil-hasil pengukuran obyektif ini, dapat ditransfer dalam skala ordinal atau interval, sesuai dengan modelnya.

Mempertimbangkan hal tersebut, maka hal-hal yang dilakukan oleh peneliti adalah sebagai berikut:

a. Data diperoleh dengan menggunakan kuisioner yang direkomendasikan berdasarkan teori Higgins (Umar, 2001:265-266), terlampir.

b. Tekanan darah responden diukur oleh seorang tenaga medis yang didatangkan langsung setiap periode penelitian (setiap bulan) dengan mneggunakan alat pengukur tekanan darah.

c. Pada variable kinerja, deskriptor mutu pekerjaan dan lainnya, langsung dinilai oleh Pimpinan Unit (dalam hal ini Ketua Jurusan Administrasi Bisnis Polnep), sehingga Ketua Jurusan tidak menjadi sampel penelitian, karena bertindak sebagai penilai kinerja.

Urutan kegiatan yang akan dilakukan :

* Data yang dibutuhkan akan ditampung pada lembar kuisioner yang berisi kedua variable di atas untuk masing-masing data karyawan. Untuk variable stres dan variable kinerja sebagian dapat ditanyakan kepada karyawan (kecuali untuk data yang memerlukan pengukuran obyektif).

* Untuk pengukuran yang berkesinambungan (longitudinal research) sudah tentu data dari Staf Pengajar diambil secara periodik, yaitu tiap bulan sehingga dapat dilihat perkembangan dari bulan ke bulan. 
* Tiap deskriptor diberi skala dengan skor 1 sampai 5 . Untuk variable stres, skor yang diberikan :

1 = sangat rendah

$4=$ tinggi

$2=$ rendah

$5=$ sangat tinggi

$3=$ sedang

Untuk prestasi kerja, skor yang diberikan:

1 = sangat jelek

$4=$ baik

2 = jelek

$5=$ sangat baik

$3=$ sedang

\section{E.4. Alat Ukur}

* Diagram

Setiap Staf Pengajar mempunyai diagram sendiri-sendiri. Diagram ini memperlihatkan titik-titik pada periode-periode penélitian dimana titiktitik itu merupakan titik temu dari nilai stres dengan nilai prestasi kerja. (lampiran hal 33-46)

* Korelasi

Alat ukur untuk mengukur seberapa besar pengaruh stres pada prestasi kerja karyawan dapat menggunakan alat ukur statistika yang disebut korelasi. Korelasi yang dipakai adalah korelasi rank spearmen (Rs)

Dimana Rumus Rank Spearmen (Rs) adalah sebagai berikut :

$$
\mathrm{Rs}=1-\frac{6 \sum d_{i}^{2}}{n\left(n^{2}-1\right)}
$$

dimana:

$$
\sum d_{i}^{2}=\sum\left[R\left(X_{i}\right)-R\left(Y_{i}\right)\right]^{2}
$$

\section{E.5. Penyajian Data dan Interpretasi}

* Jika mengacu pada Higgins, seseorang telah terkena stres kalau minimal tiga gejala stres memiliki skor tinggi, maka akan diseleksi data responden yang berkategori stres.

* Data yang terkumpul dikelompok-kelompokkan, lalu dicari skornya.

* Rata-rata skor untuk kedua variable di atas dapat dibuat dalam scatter-diagram dengan menggabungkan kedua nilai menjadi sebuah titik temu. Untuk data beberapa periode, gabungkan titik-titiknya menjadi sebuah kurva. Bandingkan dengan model teori dari|Higgins di atas.

* Nilai kinerja seseorang bisa saja dipengaruhi oleh hal-hal lain selain yang telah ditentukan di atas. Untuk mengetahui berapa besar kontribusi stres terhadap kinerja Staf Pengajar, kita dapat menghitungnya dengan menggunakan model statistika, yaitu menggunakan korelasi rank spearman (Rs).

\section{E.6. Pengujian Hipotesis}

Nilai kinerja seseorang bisa saja dipengaruhi oleh hal-hal lain selain yang telah ditentukan di atas. Untuk mengetahui berapa besar kontribusi stres terhadap kinerja Staf Pengajar, kita dapat menghitungnya dengan menggunakan model statistika, yaitu menggunakan korelasi rank spearman (Rs). 
Hipotesis penelitian :

Ho : tidak ada hubungan yang berarti antara stres dan produktivitas kerja

$\mathrm{Ha}$ : ada hubungan yang berarti antara stres dan produktivitas kerja

$$
\mathrm{Rs}=1-\frac{6 \sum d_{i}^{2}}{n\left(n^{2}-1\right)}
$$

dimana ;

$$
\sum d_{i}^{2}=\sum\left[R\left(X_{i}\right)-R\left(Y_{i}\right)\right]^{2}
$$

Berarti :

$$
\begin{aligned}
& \text { Rs }=1-\frac{6(274.5)}{14\left(14^{2}-1\right)} \\
& \text { Rs }=1-\frac{1647}{2730} \\
& \text { Rs }=1-0.6033=0,3967
\end{aligned}
$$

Dengan menggunakan table rank spearman dengan nilai $n=14$, statistik hitung ada di antara 0.05 dan 0.1 .

Kesimpulan : karena peluangnya cukup besar (antara 0.05 dan 0.1), maka Ho diterima dan menyimpulkan bahwa, dengan data penelitian yang diperoleh, tidak ada hubungan yang berarti dari dua variable tersebut yaitu antara stress dan prestasi kerja.

\section{F. PENUTUP}

\section{F.1. Kesimpulan}

Berdasarkan hasil penelitian dengan menggunakan teknik analisa data yang ada, dapat diambil kesimpulan sebagai berikut:

1. Rata-rata Staf Pengajar Jurusan Adminsitrasi Bisnis Politeknik Negeri Pontianak masih berusia muda yaitu 33 tahun. Pada usia yang masih tergolong muda, tentunya beban kerja dapat diberikan maksimal kepada setiap staf karena tenaga yang dimiliki masih cukup kuat untuk melaksanakan kerja secara maksimal, namun tetap harus diperhatikan pembagian kerja yang dibagikan agar sesuai dengan kompetensi masing-masing Staf Pengajar.

2. Diperoleh nilai Rank Spearmen (Rs) sebesar 0,3967, dengan menggunakan table rank spearman dengan nilai $n=14$, statistik hitung ada di antara 0.05 dan 0.1 .

3. Kesimpulan : karena peluangnya cukup besar (antara 0.05 dan 0.1 ), maka Ho diterima dan menyimpulkan bahwa, dengan data penelitian yang diperoleh, tidak ada hubungan yang berarti dari dua variable tersebut yaitu antara stress dan prestasi kerja. Kesimpulan 
Dedi Herdiansyah, Abdulah, dan Evi Sofiana: Pengendalian Produktivitas Kerja Staf Pengajar...

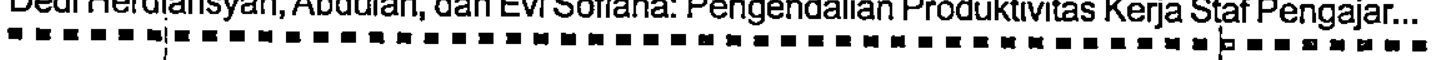

yang diperoleh, mungkin berbeda dengan hasil penelitian lain yang telah atau akan dilakukan, namun apapun yang dihasilkan oleh

\section{F.2. Saran} penelitian kali ini, turut membuktikan bahwa kinerja seseorang bisa saja dipengaruhi oleh faktor-faktor lain, selain stres kerja.

Berdasarkan hasil penelitian dan kesimpulan yang telah disajikan sebelumnya, maka peneliti menyarankan beberapa hal sebagai berikut: 1. Meski ada cara yang terbaik dalam menciptakan kinerja terbaik dari setiap staf, sehingga setia Staf merasa di beri beban tugas yang sesuai dengan kemampuan dan kapasitasnya sebagai bagian dari manajemen Jurusan administrasi Bisnis.

2. Makin banyak yang dteliti tentu hasil penelitian akan makin baik, apalagi kadar analisisnya makin dalam dan tajam. Penelitian tidak hanya mendeskripsikan apa yang ada, tetapi jika dikembangkan pada penelitian yang bersifat kausalistik yaitu mencoba untuk mencari kaitan-kaitan atau hubungan antara satu fenomena dan fenomena yang lain, sudah tentu hasil penelitiannyapun akan lebih baik, sehingga perlu penelitian lebih lanjut.

\begin{tabular}{l|l}
\hline DAFTAR PUSTAKA & \\
\hline
\end{tabular}

Umar Husein, "Riset Sumber Daya Manusia Dalam Organisasi", Penerbit PT. Gramedia Pustaka Utama, Jakarta 2001.

Mathis, Robert L., dan Jackson, John H., "Manajemen Sumber Daya Manusia", Buku 1, Penerbit Salemba Empat, Jakarta 2001.

Mathis, Robert L., dan Jackson, John H., "Manajemen Sumber Daya Manusia", Buku 2, Penerbit Salemba Empat, Jakarta 2001.

Schuler, Randall S., dan Jackson, Susan E., "Manajemen Sumber Daya Manusia : Menghadapi Abad Ke-21", Penerbit Erlangga, Jakarta, 1997.

Singarimbun, Masri dan Effendy Sofian, "Metode Penelitian Survey", LP3ES, Jakarta, 1995

Sugiyono, Prof., Dr., "Metode Penelitian Administrasi", PenerbitAlfabeta, Bandung, 2003. 


\section{Tabel 2.}

Berikut tabulasi data yang dikumpulkan melalui hasil kuisioner yang telah dilakukan :

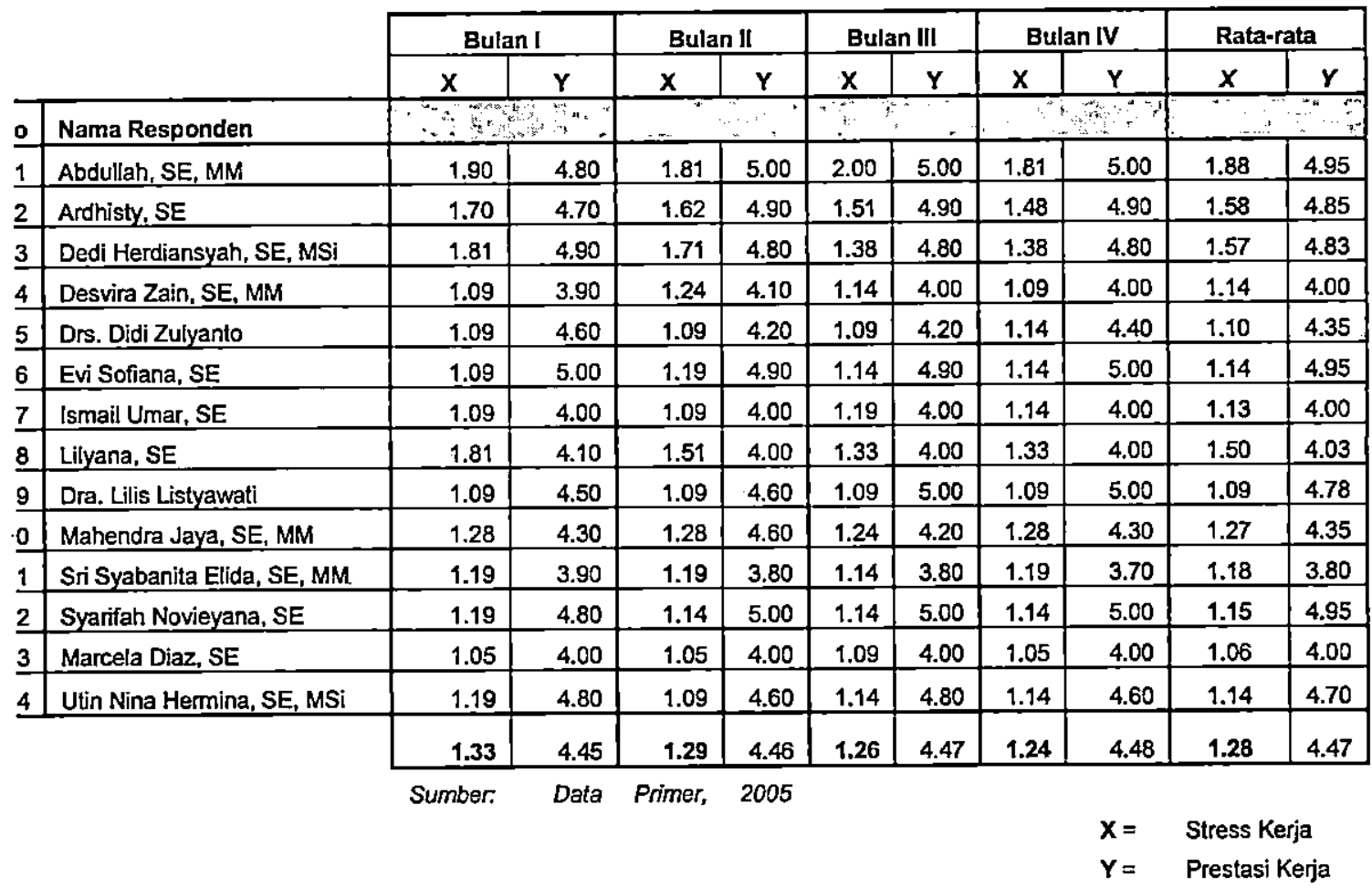

Sumber : Data Olahan, 2006 
Dedi Herdiansyah, Abdulah, dan Evi Sofiana: Pengendalian Produktivitas Kerja Staf Pengajar...

Tabel 3.

Berikut rata-rata skor dan rank dari data yang diperoleh :

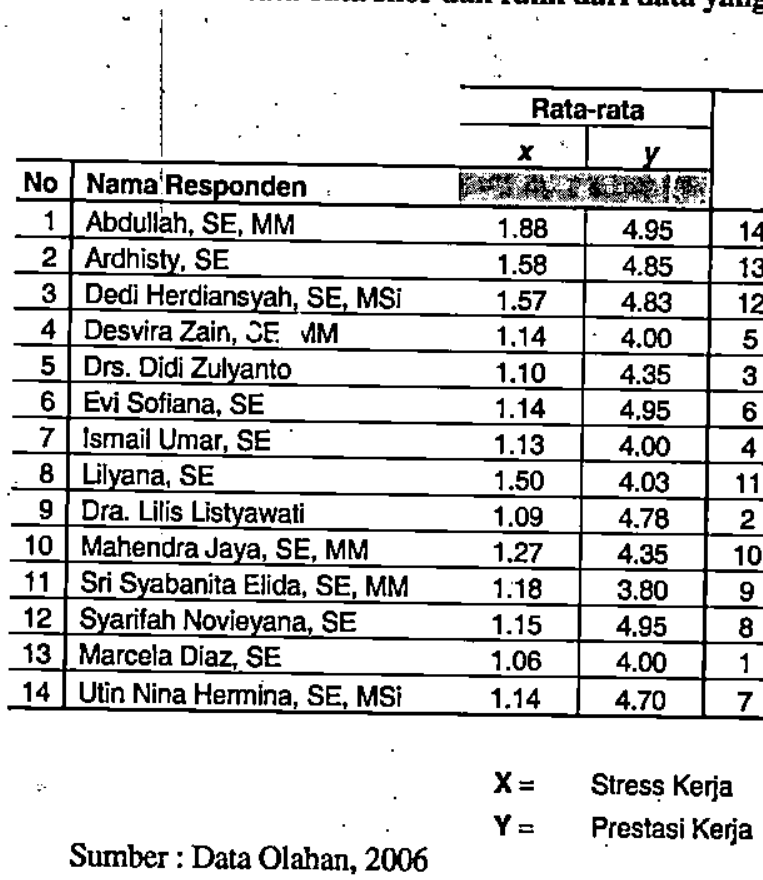

Rank

Rank-s . 